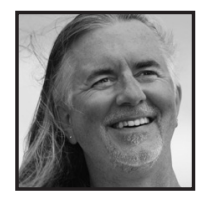

\title{
A Poem Can: Poetic Encounters
}

\section{Carl Leggo, University of British Columbia}

\begin{abstract}
All my adult life I have been a language and literacy educator in school and university classrooms. And for most of my adult life I have also been a poet. I read and write poetry; I teach poetry; I write about teaching poetry and about why poetry is important for living creatively in the world. In my poems I seek to remain open to possibilities for living poetically. I seek to see with the eyes of the heart and to hear with the ears of the heart. In a sequence of poems, citations, and ruminations, I ponder the significance of poetry.
\end{abstract}

What I felt when I wrote my first, clumsy poem was that the words were creating a world, not describing a pre-existing one. (Orr, 2002a, pp. 143-144)

What would happen if all the poets in all the world

suddenly disappeared, grew silent, lost their voices?

\footnotetext{
I

live in language, and language lives in me. I am awash in language, espoused and exposed in language. While others are seeking election, or building towers, or seeking cures for diseases, or overseeing fast-food franchises, or inventing apps we cannot live without, I read, write, and teach poetry. I have enjoyed the immense privilege of pursuing an academic career at the University of British Columbia for more than a quarter century. UBC letterhead declares that the university is "a place of mind," and, without doubt, it is. I am proud to be a professor in this internationally renowned "place of mind," but I still wonder what might unfold if the university boldly pronounced
} 
itself "a place of mindfulness." I choose, deliberately and imaginatively, to live mindfully in the "place of mind." UBC also has a longstanding Latin motto: Tuum Est, or "it is up to you." I like this motto because it reminds me that I am daily making creative decisions about how I choose to live artfully, poetically, spiritually, intellectually, and heartfully.

Heaney (1995) writes:

I had already begun a journey into the wideness of the world. This in turn became a journey into the wideness of language, a journey where each point of arrivalwhether in one's poetry or one's life-turned out to be a stepping stone rather than a destination... (p. 11)

Like Heaney I know how journeying in the wideness of the world entails "a journey into the wideness of language." I have been reading and writing poetry for decades. I am never sure that I understand very much or that I have much to say, but I am compelled to promote poetry. Why is a poem significant? Do we really need poems, or is that just a poet's hope for endorsement and response? What can a poem do? Like Dawn (2013) in her moving memoir, How Poetry Saved My Life, I hold fast to the creative energy of poetry for helping us live with hope and wellness in the world. Dawn asks, "What does it mean to be given the rare and privileged opportunity to have a voice? To me, it means possibility and responsibility" (p. 13). As I ruminate on this "possibility and responsibility," I consider four ways I can complete the sentence stem: A poem can....

\section{A poem can heal.}

under a moon, almost full, I am learning to listen for cherry blossoms like a new alphabet for calling out love

I have known much brokenness in my life. I wear the wounds and scars of many decisions, disappointments, desires, debts, and dreams. I turned to poetry as a young man whose life seemed to be swirling out of control. I was tangled in one crisis after another. I wrote in a journal, seeking some explanation or narration for the chaos that simultaneously sapped my energy like a heavy cloud or tossed me about like a scarecrow in a whirlwind. As I wrote in my journal, I slowly learned that writing poetry can be healing. Orr (2002b) promotes the "enormous transformative 
power" (p. 6) of poetry and story-making because they help us "to live" (p. 21). In all my writing, I am seeking ways to live with wellness. I heartily agree with Neilsen Glenn (2011) that, "poetry is the grace we can find in the everyday" (p. 117). All my life I have been searching. I am just never sure if I know what I am searching for. Like Gide (1970), "all through my life I have never sought to know myself; that is to say I have never sought myself" (p. 197). I search, but I am not searching "to know myself." I search in order to live, to become, to explore possibilities in a kind of creative wanderlust. I am engaged in "the perpetual and elusive process of becoming" (p. 197). Poetry is my companion on the journey.

\section{Thirteen Meditations in the Dentist's Chair}

1

in the liminal space of February

I take stock like a shopkeeper:

go to the dentist

buy tires for the CRV

remember colleagues

who might need prayer

2

beginning the day

with a root canal

reminds me

how much

I love life

3

there are

many kinds of love

and I have been blessed

to know some,

likely far more

than many

but long love

lasting love

love shaped on a last

is the love

I thank God for

daily 
4

we join God

in prayer

not because we need

to remind God

or persuade God

or cajole God

like an inattentive parent

checking Facebook

but because God

invites us to enter

the divine energy

of endless creation

5

sitting in Dr. Carter's chair

I pray for friends:

Harry is dying in Maple Ridge

Regina is living with cancer

William is dying in North Van

Doris is living with cancer

6

Carrie claims nothing means

anything anymore

but doesn't everything mean

something, perhaps

we have forgotten how to be

7

what if my prayers are

foolish and futile,

offered into the stratosphere

like an expulsion of air?

what if there is no God? 


\section{8}

prayer is a way of breathing

oxygen spirit pneuma

prayer is a way of leaning into the world, refusing to surrender

\section{9}

I don't know what prayer is but in the moments of each day something won't let me go, something tantalizing, desire's constant goad

10

perhaps prayer is a message tapped in Morse code on the stone walls of our cells

11

at a conference in San Francisco with thousands of other educators one colleague said, I am suspicious of anyone who talks about hope

12

would I stop praying even if somebody

proved definitively God doesn't exist?

13

on this gray wet day in Lent while the world rotates with slow heavy rhythms, I offer a brief prayer as I remember you fondly, often, a hallowed haunting 


\section{A poem can teach us.}

may our teaching sing with the vital voices of poets in love, longing for the possibilities of words for translating each day's demands

It is a marvellous privilege to be a teacher-to engage daily with others in reading and writing, talking and listening, making and interpreting. I am now a Facebook friend with former students I taught in the 1970s. They were 12 or 13 years old when I first met them in our grade seven classroom. I was 22. From the stories they post on Facebook, I know that their stories have been at least as complicated and tangled as mine. I wonder what we learned together. I remember the copious worksheets and notes on the blackboard and lists of rules, definitions, and facts. I was always seeking to control the curriculum, the classroom, the commotion, the chaos. Gide (1970) reminds me that, "we are deceived by words, for language imposes on us more logic than often exists in life; and that the most precious part of ourselves is that which remains unformulated" (p. 197). I needed more poetry when I began teaching. Poetry is not wedded (or welded) to logic. While poetry can certainly avail of the rhetorical purposes and processes of logical thinking and discourse, poetry thrives on imagery, music, intuition, imagination, indirection, and silence. Poetry works with form in order to challenge formula and formulaic uses of language.

\section{Heavy Work}

In your poetry language is doing the heavy work.

(anonymous reviewer)

\section{a}

deciding what to leave

in heavy work

b

belonging longing to be

C

instead of being in opposition

I want to be in apposition 


\section{d}

there is no prize in surprize

\section{e}

what happened happened

\section{$f$}

fun fundament fundamentalism

forgets the fundament of fun

g

untangling the knot in monotony metonymy

h

how are you? well you?

well I think

not sure? not really

not really? a real knot

i

my calling is to love words

in their mystery

j

a poem is wild with longing

the longing for light

and night

k

I want to live

in the world

like a word

that lives love

I

angry with acronyms: IT, cIRcle, FGPS FSC

acrimonious acronyms arousing arachnophobia 
m

morning mourning moaning Mondaymoaning

n

aesthetic

writing life into meaning

an/aesthetic

writing meaning into life

o

if I write on this page without ink,

am I writing? can I think without ink?

p

I carry my working class baggage

like a turtle shell

Sisyphus' rock

a hoarder's U-Haul

q

I have wrapped myself in a quilt of guilt

$\mathbf{r}$

consumed, but not defined

by regrets still

leaning into each day's hope

$\mathbf{S}$

it was a dark and stormy

morning all the difference

t

is life a run-on sentence?

u

when I receive a speeding ticket,

I include it in my CV as a citation 


\title{
V
}

my daily planner fills up faster

than a Newfoundland backyard

in a November snowstorm

w
delusions of both
gravity and levity

$\mathbf{x}$

after his wife Ruth died, a neighbour said,

he is now ruthless

y

yearning for learning

yearning for you your yearning

learning with yearning

Z

deciding what to leave

out heavy work

\section{A poem can show us the way.}

\author{
poetry is fired \\ in the alchemy \\ of the alphabet \\ where letters know \\ our stories steeped \\ in autumn's hope
}

I grew up in Newfoundland where winter is typically long, where the wind can stir up a snowstorm without warning. I have often leaned into winter storms, seeking my way in the wind-whipped snow that renders everything white and formless. I have been lost in snowstorms. I have been lost in many stories, too. On countless occasions, I have not been able to see the beginning of my day's journey, and I have certainly not been able to see any destination I might be hoping for, any destination waiting for me. Poetry is a companion on the way. Poetry accompanies me on the journey of 
being and becoming. Parini (2008) notes that, "the truth of poetry is symbolic truth, in that it cannot be verified by conventional means. It differs massively from scientific or philosophical truth, both of which make truth claims that lie outside the boundaries of poetry" (p. 100). To engage with poetry is to live in the heart's way, to acknowledge the truthfulness of emotion and experience as significant teachers. We read and write poetry because poetry weaves language in texts that speak to us and move us and tantalize us. But, as Parini claims, "the poem is also a labyrinth. One makes a journey through the poem, from beginning to end, moving within the space of the work, its boundaries, tracking its labyrinth or pattern" (pp. 100-101). Like each living day, we seek the way in a labyrinth. Poetry can show us the way.

\section{Fragments or Fractals}

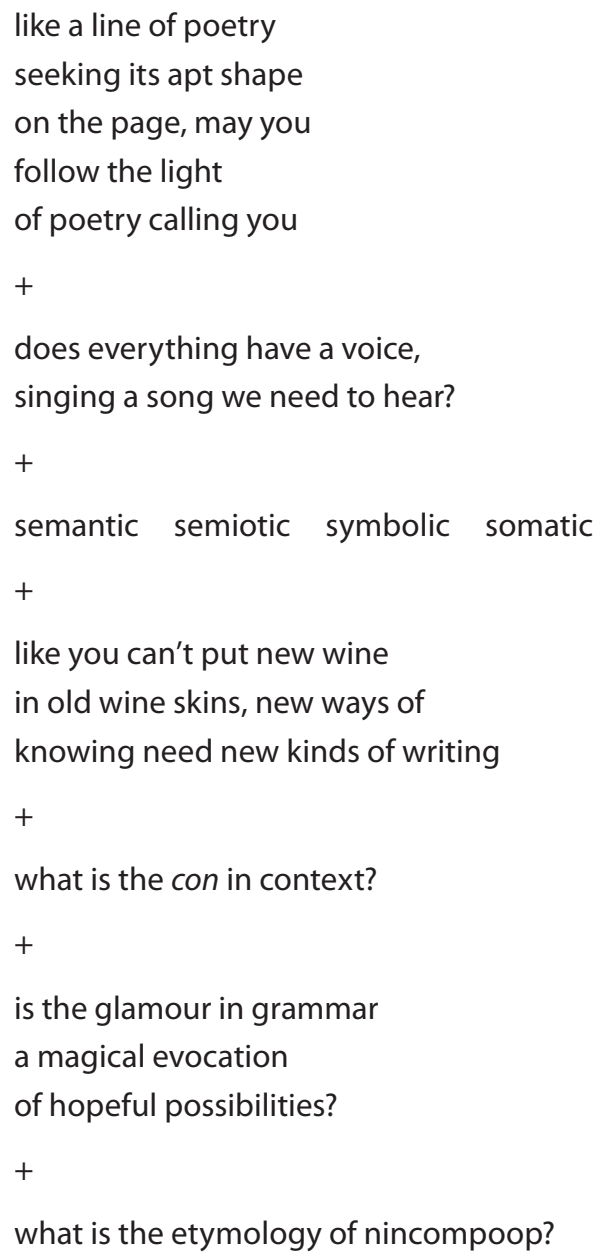


beginning a new cliché:

love makes the world go Mobius

$+$

found poem

(did it know it was lost?)

$+$

a poem is porous

but not poor

$+$

what is the syn in syntax?

$+$

he lost his story

and with it, his way

$+$

since my life is a collection

of short stories I will

begin a new draft

$+$

the root of truth is play

$+$

what is the middle of a muddle?

$+$

fund (past tense of fun)

$+$

love is indefinable, and hence poets

are always seeking to define it

$+$

what do you hear when

you listen to a flower? 


\title{
4. A poem can linger.
}

\author{
the early evening light \\ in my neighbour's cedar \\ invites me to be still
}

When I moved to the University of British Columbia in 1990, I moved into an office in Ponderosa Annex E, and during 25 years, I gathered many books and memories. Recently, I packed up the remnants of my old UBC office and moved to a new location in a new building where I am beginning new stories. The new building is called Ponderosa Commons. My UBC offices have always been located near a gigantic Ponderosa pine. My Department Head saw me looking out my new office window, attending to the Ponderosa pine that animates my new view, and he wondered if a poem might be coming soon. Of course!

\section{Pondering the Ponderosa Pine}

My work is rooted in silence.

It grows out of deep beds

of contemplation, where words,

which are living things,

can form and re-form

into new wholes.

(Jeanette Winterson)

for more than twenty-five years you have greeted me

on treks to Scarfe for meetings and more meetings, or seeking coffee, the high-octane fuel of scholars, or sitting in your shade, sipping coffee, pondering if I really need to attend another meeting

I will not render you a metaphor

in this poem

I will not anthropomorphize you

like a Disney cartoon

I will not sentimentalize your saga of survival

from weather, pests, and chainsaws

I will not pretend hermeneutically

I know your essence 
I will not claim I can name

your existence in

post-structuralist

post-materialist

post-human

post-modern

post-feminist

post-colonialist

discourses, enough posts to build a fence around Ben Cartwright's Ponderosa

your wildness cannot be contained in my poem

any more than I can hold the moon's fullness in a pail

ever green, ever rooted, ever patient,

ever willing to teach us if we are willing to learn

teach us to remember we are guests

on an ancient land with countless stories

teach us to walk tenderly with one another,

filled with memories and hopes for others, too

teach us to know this place of mind

is also a place of mindfulness

in these last years I have at UBC

I will loiter often with you, and even if

I write fewer poems or papers, I might

yet learn to live like a scholar who knows

learning always begins with lingering

we no longer dwell in an annex

like an appendix or supplement

we will not pine for the Ponderosa Annexes

as we settle into the Ponderosa Commons 
let us now dance an Argentinian tango

with light and shadow, with the rhythms

of the seasons, with the ebb and flow

of students and colleagues as we compose

new stories with the alphabet's possibilities,

new stories rooted in memory and imagination

\section{In/conclusion}

I heartily agree with Orr (2002b) that, "an awareness of the disorderly and chaotic world we inhabit is a fundamental aspect of being human" (p. 16). Poetry is both a part of that awareness and a significant epistemological and ontological way to engage with inhabiting a "chaotic world" in words so we can be and become human.

In ways I understand only a little, poetry fills me with hope for each day's journey.

May we continue our searching for new possibilities for living well together.

Let our scholarship sing in new voices, call out with enthusiasm for the possibilities

of loving poetry and living poetically.

\section{References}

Dawn, A. (2013). How poetry saved my life. Vancouver: Arsenal Pulp Press.

Gide, A. (1970). Fruits of the earth. Harmondsworth: Penguin Books.

Heaney, S. (1995). Crediting poetry. Loughcrew: The Gallery Press.

Neilsen Glenn, L. (2011). Threading light: Explorations in loss and poetry. Regina: Hagios Press.
Orr, G. (2002a). The blessing. Tulsa: Council Oak Books.

Orr, G. (2002b). Poetry as survival. Athens: University of Georgia Press.

Parini, J. (2008). Why poetry matters. New Haven: Yale University Press. 


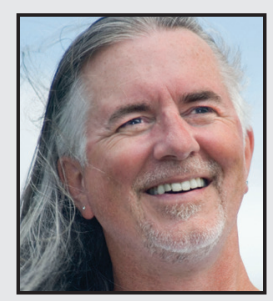

Carl Leggo is a happy poet and professor in the Department of Language and Literacy Education at the University of British Columbia. His books include: Growing Up Perpendicular on the Side of a Hill; View From My Mother's House; Come-By-Chance; Teaching to Wonder: Responding to Poetry in the Secondary Classroom; Lifewriting as Literary Métissage and an Ethos for Our Times (co-authored with Erika Hasebe-Ludt and Cynthia Chambers); Creative Expression, Creative Education (co-edited with Robert Kelly); Poetic Inquiry: Vibrant Voices in the Social Sciences (co-edited with Monica Prendergast and Pauline Sameshima); and Sailing in a Concrete Boat: A Teacher's Journey. 